\title{
Citizens' Perception of Corruption and Transparency as Determinants of Public Trust in Local Government in Ukraine
}

\author{
Stanislav Rieznik \\ Hwan-Beom Lee"*

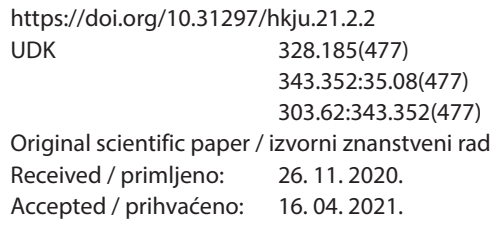

Trust in government plays an essential role in ensuring the legitimacy and resilience of a country's political system. The aim of this study is to examine the perceived levels of corruption and transparency as factors influencing trust in local government, as well as the relationships between them, by obtaining a statistical generalisation of the respondents' ( $n=403)$ attitudes and opinions towards the lo-

* Stanislav Rieznik, PhD candidate, Department of Public Administration, Yeungnam University, South Korea (Odjel za javnu upravu, Sveučilište Yeungnam, Južna Koreja, e-mail: stanislav@ynu.ac.kr)

ORCID ID: https://orcid.org/0000-0002-6800-971X

** Hwan-Beom Lee, Professor at the Department of Public Administration, Yeungnam University, South Korea (Odjel za javnu upravu, Sveučilište Yeungnam, Južna Koreja, e-mail: hblee@ynu.ac.kr)

ORCID ID: https://orcid.org/0000-0003-3002-0486 
cal government of one of the recently formed amalgamated territorial communities in Ukraine. The regression-based bootstrapping approach was applied to test the conceptual model and hypotheses using the Statistical Package for Social Sciences (SPSS) 25.0 software. The results of the study demonstrate the complex nature of the relationship between the variables and highlight some important issues regarding the perception of transparency, the role it plays in curbing corruption and improving public confidence in local government, which provides a basis for further systematic research on this topic.

Keywords: citizens-state relationships, state-building, local government, trust in government, corruption, transparency, Ukraine

\section{Introduction}

Trust in government plays a crucial role in ensuring the legitimacy and resilience of a country's political system (OECD, 2013). Trust is important for social cohesion, and also leads to a reduction in transaction costs in political and economic and even social relations (Fukuyama, 2001). Citizens' trust in the government seems particularly important in times of economic crises and political unrest. Ukraine's political stability is an important factor not only for the country itself, but also for the neighbouring European countries. Following the Revolution of Dignity in 2014, the country's territorial integrity was threatened. Taking advantage of the temporary destabilisation of the political situation in Ukraine, Russia annexed the Crimean peninsula and initiated an armed conflict in eastern Ukraine. The Ukrainian government is now concentrating its efforts to resolve this conflict and to strengthen the state as a whole. In the process of strengthening the state and political stability in Ukraine, state-building at the local level plays an essential role (Lindegaard \& Webster, 2018).

In many Eastern European countries, the political and economic failure of authoritarian, centralised socialist regimes prompted the beginning of decentralisation reforms (Aristovnik, 2012). Ukraine is one of the Eastern European countries of the former Soviet Union, so it shares a number of common features in the field of local government with them. Until recently, the Ukrainian system of regional and local government was typical of 
post-Soviet states and, although subject to some adjustments, reflected the Soviet system of local government from top to bottom, consisting of a vertically hierarchical line of councils, from village councils to the Verkhorna Rada (the Ukrainian parliament). As noted by Van de Walle (2011), it is the decline in trust in government that serves as a catalyst for New Public Management-style reforms aimed primarily at increasing transparency and public awareness by providing factual knowledge about the performance of government agencies.

The Government of Ukraine is currently carrying out a decentralisation reform, designed to transform local governments and make them more efficient and effective (Romanova \& Umland, 2019). With regard to the territorial governance approach, Ukraine is a unitary state with 24 oblasts, one autonomous republic (AR Crimea), and two cities with special status: Kyiv and Sevastopol. Prior to the reforms of administrative and financial decentralisation, these regions were divided into 490 districts (rayons), there were approximately 10,900 municipalities at the local level, and state power in Ukraine was highly concentrated (European Union, 2011). Fiscal decentralisation was introduced in early 2015, and small local municipalities began to merge into larger and more self-sustaining "amalgamated territorial communities" (ATCs). Such ATCs have been given significant powers to collect taxes and now have direct inter-budgetary relations with the state budget, as well as additional responsibilities for the provision of public services and the promotion of infrastructure (CMU, 2020). The process of New Public Management-inspired institutional reforms aimed at improving human resources and results-oriented management has also intensified since the adoption of the new civil service law (Bilous \& Tyshchuk, 2019).

The success of decentralisation and institutional reforms in Ukraine has close links with citizens' trust in the government. Successful reforms will lead to improved accountability and responsiveness of local governments, which in turn may improve trust in them and, in the long run, the relationship between citizens and the state (Lindegaard \& Webster, 2018). The constant drive for reforms implementation is largely dependent on how citizens perceive the improvements of local government and local conditions through initial reforms, though attempts to ensure a positive perception take place in a difficult environment of a very low level of trust in public authorities.

According to the Ukrainian scholar community, the problem of preventing and overcoming corruption is one of the most important for the coun- 
try at the present stage of its development. Corruption, through the effect of a chain reaction, creates a whole range of other systemic problems such as threats to the rule of law and the stability of democratic processes, thus undermining the foundations of public administration (Gerasymenko, Splavinska \& Pavliv, 2018). Zakharchuk (2015), believes that, in particular, service in the local government is a favourable environment where corruption tends to flourish, and insists that the issue of preventing corruption in local governments needs to be systematically studied. Therefore, promoting the implementation of the principles of transparency and openness of information in public authorities in Ukraine is one of the effective ways to minimise possible manifestations of corruption over time. Hence, it would be interesting to investigate the features of citizens' trust in political processes and local government and to examine their perception of corruption and transparency as factors influencing it, as well as the relationships between them, on the example of a newly created local administrative unit. Studying the issue of citizens' trust in government on the example of amalgamated territorial communities will help to see whether the emphasis on local self-government can be a promising approach in terms of strengthening political stabilisation and state-building in Ukraine, as well as in the case of a highly centralised post-Soviet state. Studying such a country context would also add to the current literature on institutional trust in the transitional countries of the former Soviet Union, known as having a low trust climate, by deepening the understanding of its nature and of the factors influencing it. Thus, one of the newly formed amalgamated territorial communities was chosen as a case for research. The setting of local self-government in Ukraine was used to develop a set of hypotheses based on the existing theories, generally suggesting the negative effect of corruption on trust on the one hand, and positive consequences of improved transparency on the other. To test these hypotheses, containing both direct and indirect relationships between perceived levels of local government transparency, corruption and trust, a quantitative methodology was applied through the conduct of a survey.

The article continues as follows. The next section will review the existing literature and theories that may be useful in understanding the concepts of trust in government, as well as of corruption and transparency as influencing factors. It will then describe specific arguments and hypotheses that represent the most likely relationship between the variables and citizens' views on local government. Then the method and design of the study will be presented followed by the results, findings, and implications. 
Finally, the limitations of the study and the outline for future research are presented in the last section.

\section{Literature and Theoretical Review in the Context of Local Government}

As a place of interaction between citizens and those chosen to manage public goods, local governments have a major impact on citizens' daily lives. In many countries with a multilevel structure of government, local governments play a key role in implementing policy decisions. People thus give different credibility to central and local governments. This is partly because people are expecting better accessibility and higher responsibility from local government agencies as they are closer to the citizens (Beshi \& Kaur, 2019).

Some empirical examples of confidence in central and local governments show that citizens tend to have more trust in local governments rather than central as they connect with local government officials more often and share common interests with them (Cooper, Gibbs \& Brennan, 2008). Based on the Results of the Fourth Wave of Sociological Research conducted by the Council of Europe (2019), when Ukrainians were asked who they trust the most on political issues, no single political institution or level crossed the $10 \%$ mark. Local authorities with about $8.4 \%$ had the highest level of trust among all government bodies. Although these figures are not significant, they do have a significant advantage over trust in other levels of government - the district, oblast, and parliament received only about $1 \%$. This means that there is potential for the development of local relations between citizens and the state. Moreover, in terms of enhancing political stabilisation, the emphasis on local government can be a promising approach.

\subsection{Trust in Government}

The literature on trust is extensive. Studying the various definitions of trust used in different disciplines, Rousseau and colleagues (1998, pp. 394-395) concluded that there are no significant differences between disciplines in definitions of trust, and, if generalising, trust can be defined as 
a psychological state involving the intention of one party to accept vulnerability based on positive expectations from the behaviour of another.

On this basis, in defining public trust in government, Hetherington (1998) defines trust as a basic value orientation toward a government based on how well the government performs in accordance with the normative expectations of the people. Here, social and political trust can be seen as the two main elements of trust in the authorities. The first one regards a confidence of citizens in their social community, whereas political trust refers to confidence in the government and government institutions. Citizens' trust in government, therefore, can be regarded as confidence in the government, or political trust, which includes macro and institution-based trust (OECD, 2013, p. 21). A certain level of public confidence in the government is a prerequisite for the effective functioning of public institutions, especially when it comes to implementing structural reforms. To be effective and sustainable, such reforms require broad social and political consensus, as they often involve sacrificing short-term gratification for long-term benefits. With a low level of citizens' confidence in the government, the former will be guided by immediate and partial benefits, and thus will encourage politicians to seek short-term and opportunistic benefits (OECD, 2013). Trust in government, trust between society and the state is especially important in crisis situations. When people believe that the state knows what it is doing, wants the best for them, and can protect them, then it is easier for the government to focus on the core functions of governance.

Research on the phenomenon of trust and the relationship between institutional trust and other aspects of governance has recently received a considerable amount of attention. Some studies of such relationships have positioned trust as an independent variable and found that it is associated with numerous positive effects. Klesner (2007) identified that interpersonal trust and citizen involvement are crucial factors that stimulate economic development and promote effective democratic institutions. Other studies, on the other hand, believe that trust is a product of institutional performance. Lanin and Hermanto (2019) found that increasing citizens' satisfaction with public services could lead to increased public confidence in local government institutions. Thus, cultivating and promoting institutional trust has a number of positive consequences. Lopushyns'ky (2013), analysing trust in government as a state-building factor in Ukraine, argues that public trust in government is absolutely necessary when the state wants to carry out deep socio-political and economic transformations. In this light, study of the factors influencing institutional trust seems impor- 
tant and appropriate. Among the determinants of trust, corruption can be considered as one of the important factors.

\subsection{Corruption}

In recent decades, the perception of government corruption has gone beyond abstract debate about what corruption is. The focus of the discussion has shifted to practical research on how it is formed, on perceptions of corruption in the political, social and economic sense, and what the controls for corruption are (for more details, see Dimant \& Tosato, 2017). Although there are differences in the methods of expression between researchers, it is difficult to notice fundamental differences in the definition of local government corruption. In addition, previous studies do not show a conceptual description of local government corruption that differs from corruption in general. Thus, local government corruption can be defined as an act of violation of public interests by an official of a local government institution through abuse of official position for private gain (Pozsgai-Alvarez, 2019).

Corruption at the local and regional levels largely reflects the problems of corruption at the national level. It leads to specific problems, especially difficult for developing countries (Schöberlein, 2019). The city or municipal level is the level at which the relationship between government and the public is particularly visible and can play a significant role in national development. There are several types of political corruption that occur at the local level, such as bribery, embezzlement, extortion, nepotism and patronage. Some are more common than others, and some are more common to local governments than to higher levels of government. Therefore, the fight against corruption at the local level is extremely important, as it can increase competition, increase household income and local budget revenues, improve service delivery and, as a result, strengthen trust in public institutions (Schöberlein, 2019).

According to the Council of Europe (2017), in 2017 about 44\% of the population considered corruption to be the most important problem in Ukraine, and 90\% believed that corruption was widespread. Gerasymenko and colleagues (2018) note that although corruption is considered a global problem and is present in every country, in Ukraine it has become one of the threats to national security and further democratic development of the state. In particular, civil service in local governments is considered a favourable environment where corruption tends to thrive (see Zakharchuk, 2015). 


\subsection{Transparency}

Transparency is usually seen as a major practical step taken to mitigate corruption (Lindstedt \& Naurin, 2010), and has also been proposed as a solution to the growing public distrust of the government. Transparency acts as a deterrent to corruption by encouraging public awareness and preventing civil servants from misusing public service for personal gain (Florini, 2007). In the relevant literature, transparency is commonly described as an open flow of information (Piotrowski, 2017), and this notion of openness is strongly emphasised in the relationship between government and citizens. According to Oliver $(2004$, p. 2), the presence of an observer and the object of observation, as well as an appropriate approach to observation, can be considered to be the three key elements of transparency. This view follows from the principal-agent theory, according to which the principal (observer) monitors the agent's actions to check if the agent is following the agreement (Prat, 2006). Following this point of view, transparency can be defined as the disclosure or dissemination of information about the actions of one party, which allows the other party to control the work of the first party, constituting an institutional relationship in which information is exchanged (Grimmelikhuijsen, 2012, p. 55). Simply put, transparency promotes accountability and provides citizens with information about government activities. Public accountability is an important feature of effective local or regional government. In the absence of public accountability, corruption and bribery can flourish, inevitably leading to a loss of trust in government (Council of Europe, 2017).

With regard to the situation in Ukraine, Volianska (2020) points to a gradual decline of trust in political institutions in Ukraine, which is associated with unresolved issues of the transparency and efficiency of public authorities. It was also noted that the low level of trust in Ukraine is in line with the tendencies of most post-socialist countries.

\section{Model and Hypotheses Development}

The research model (Figure 1) illustrates the hypotheses presuming inter-relationships between perceived corruption, local government transparency, and citizens' trust in local government based on the review of the literature. It is expected to see a negative direct impact of the perceived level of corruption on the citizens' perception of trust in local government as well as some indirect relationships that will be developed hereunder. 
Since current research focuses on the issues of trust and perceptions of corruption and transparency by citizens of one post-Soviet state, it is important to consider the long-term impact of the Soviet legacy on the minds of people (most notably in the case of a group of older people), which may increase mistrust of government and influence their perception of corruption. On the other hand, the respondents' age can also play an important role in the perception of transparency, as previous research (see sub-section 3.2 below) has shown that young people tend to perceive government institutions as more transparent. Thus, it was decided to incorporate into the research model the variable age of the respondents as a specific (especially in the context of post-Soviet states) indicator.

Figure 1. General research model

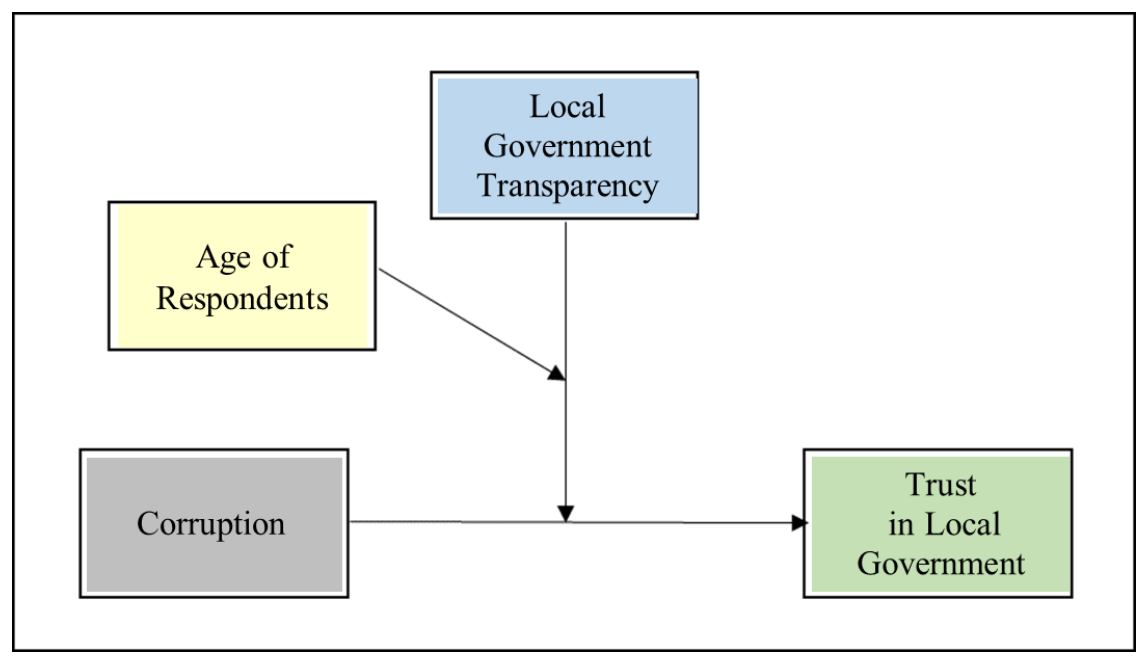

Source: Authors.

\subsection{The Relationship between Perceived Corruption, Government Transparency, and Citizens' Trust in Local Government}

Considering government performance and the efficiency of public services, there is a key factor that undermines public respect for government as a service provider and disappoints citizens (Park \& Blenkinsopp, 2011). Several scholars share the view of a performance-based approach 
that links trust in government with real government performance. The approach states that those institutions that work well inspire confidence in citizens (Mishler \& Rose, 2001, p. 31), and they further consider such institutions to be reliable on the basis of appropriate institutional images. Institutional trust illustrates the positive expectations of citizens towards members of such institutions that they will follow the necessary procedures, and this will lead to positive outcomes both for them and for the society as a whole (Askvik, Jamil \& Dhakal, 2011). However, if local government bodies along with the central government fail to improve the performance of local government institutions, the legitimacy of both local government bodies and of the central government becomes questionable.

A review of the literature on corruption, in particular of the studies examining the effects of corruption, considering corruption as an independent variable, shows that they are based on two competing approaches: functionalist and Weberian. Both theories show how corruption in the society shapes public attitudes and perceptions of government. The grease-the-wheels-hypothesis, which is the first approach, emerged in the 1960s and suggested that corruption can accelerate economic activity in a weak governance environment by acting as a lubricant for bureaucratic and political mechanisms. By contrast, according to the Weberian approach, corruption not only has a negative impact on the financial sector, but also reduces the efficiency of government in the equitable, balanced and efficient delivery of public goods and services (Cooray \& Schneider, 2018).

Empirical research generally supports the Weberian approach. In support of this view, a study by Méon and Sekkat (2005) states that corruption not only hinders growth and investment, but can have even worse consequences in the case of poor governance. Reinikka and Svensson (2005) found that corruption had a detrimental effect on the accumulation of human capital. Corruption also undermines public confidence in the government system. For example, Anderson and Tverdova (2003) investigated whether increased awareness of corruption at the national level related to the declined citizens' trust in civil servants. It has been found that citizens of democratic countries where the perceived corruption level is higher are unlikely to trust civil servants. Consistent with previous research, Bauhr and Grimes (2014) found that as the perception of corruption became more serious, the institutional trust of citizens declined.

Local governments are more susceptible to corruption, as interactions between the public and officials are more individual in nature and occur more often than at higher levels. Compared to higher levels of government, corruption at the local level is more visible to citizens and can have 
more serious consequences in terms of reducing citizens' trust in public institutions. Local government corruption can be defined as an act of infringement of public interest by local government officials by abusing the power entrusted to them for private gain (Pozsgai-Alvarez, 2019). Yates and Graycar (2020) note that local government officials do not always recognise corruption in the local government, and if they do, they do not report it. Even if cases of corruption are recognised and reported, they often do not receive an adequate response. Thus, serious corruption at the local government level may go unpunished and such a negative experience undermines citizens' trust in the government and the general belief in democratic processes. According to Park and Blenkinsopp (2011), corruption creates a negative perception of public service performance among citizens, and subsequently reduces their overall level of trust in government. Therefore, when developing the current research model (Figure 1), corruption was expected to show a negative relationship with and reduce citizens' trust in local governments. Thus, the first hypothesis states that:

$\mathrm{H}_{1}$ : Corruption is negatively related to trust in local government. As the citizens' perception of corruption became more serious, trust in local government declined.

As noted by Van de Valle (2011), it is the decline in public confidence in government, even if only at the level of perception, that is the main driver of new public administration reforms aimed at promoting transparency in government performance to strengthen public confidence. Grimmelikhuijsen (2012), however, argues that transparency may not necessarily increase trust, and may even have the opposite effect if citizens are disappointed with how transparent government is. The results of a study by Grimmelikhuijsen, Porumbescu, and Tobin (2013) show that the negative impact of transparency on trust in government may be due to certain national and cultural characteristics that affect people's perception and assessment of government transparency.

Nonetheless, in general, especially from the point of view of practitioners, transparency is perceived as a key factor positively influencing trust in government (Pasquier \& Mabillard, 2015). According to proponents of transparency, such as Cook, Jacobs, and Kim (2010), lack of sufficient information about government processes and performance is one of the reasons why citizens do not trust the government, and therefore regular disclosure of information about government activity is extremely important to increase public confidence. Park and Blenkinsopp (2011) also reaffirmed this relationship between transparency and trust in government. Therefore, information should be made available and searchable by citi- 
zens. It also must be clearly processed and understood by individuals in order for the system to be considered transparent. The basic idea behind this view is that citizens will trust the government when they know what a government is and how it works (Bok, 1997). Thus, it is hypnotized that: $\mathrm{H}_{2}$ : Increasing citizens' perception of the transparency of local government has a positive effect on the trust in local authorities.

Although government transparency is an issue that is widely discussed in the literature, it is not often seen as a determinant of corruption (Lindstedt \& Naurin 2010). Jimenez and Albalate (2018) note that by increasing the level of transparency and providing more information to citizens, local authorities reduce the likelihood of encountering cases of corruption and vice versa. Transparency leads to improved public control, which correlates with a reduction in corruption. The principal-agent theory shows the mechanism by which transparency can mitigate corruption. The government, which acts as an agent, usually does not provide adequate information about the results of its activities to the citizens (voters), who are represented here as principals. Low levels of transparency systematically distort the signal that voters use to test the effectiveness of government (Kolstad \& Wiig, 2009), and thus create an enabling environment for corruption. When the principal is not able to effectively control the agent, the agent has the opportunity to betray the interests of the principal, pursuing their own interests.

Transparency, which impedes this discretionary space of the government, reduces the information asymmetry between the principal and the agent (Menocal, 2015) and improves the potential of voters to keep a close check on the activity of the government chosen to prevent rent-seeking strategies. Therefore, local government transparency is predicted to moderate the negative effect of corruption on trust in local government. Thus, the third hypothesis says:

$\mathrm{H}_{3 a}$ : Local government transparency moderates the relationship between corruption and trust in local government.

Moreover, increased government transparency and anti-corruption efforts are expected to lead to greater public satisfaction with the government and increased citizens' trust in local authorities. Simply put, the more government makes efforts to be open, the more citizens perceive it as transparent and less corrupted and even if corruption is discovered, the negative effect on trust will not be as significant as at a low level of perceived transparency.

$\mathrm{H}_{3 \mathrm{~b}}$ : The negative effect of corruption on trust in local government weakens as citizens' perception of local government transparency becomes higher. 


\subsection{Micro-Level Factor: Age as a Control Variable}

Another aspect which is interesting to investigate is what effect age has on the citizens' perception of transparency and consequently on their trust in government. Looking for ways to increase public confidence, governments are increasingly focusing on developing open government strategies based on the publication of open data, which will increase the transparency and availability of information (Meijer, 2015). Among the works that investigated the issue of trust using the respondents' age as one of the control variables, some found that young people trust national institutions more than older people (Van der Meer \& Hakhverdian, 2017), while others show the opposite trend (Twenge, Campbell \& Carter, 2014).

However, moving to the level of trust in European institutions, most of the studies here indicate that the level of trust decreases with the increasing age of the respondents (Arnold, Sapir \& Zapryanova, 2012). Such a tendency has to do with the fact that young people more often and more willingly turn to using modern communication platforms and technologies in search of the necessary information, as they are more aware of the potential role of the Internet in the creation of and access to public content (Gonzálvez-Gallego \& Nieto-Torrejón, 2021). Thus, it can be assumed that compared to older people, young people assess government efforts as being more transparent, and tend to trust government agencies more when they publish public and open data. This will also affect the perception of corruption and the effect it has on trust. Therefore, hypotheses four states:

$\mathrm{H}_{4 \mathrm{a}}$ : For younger people, there is a stronger positive relationship between perceived transparency and trust in local government.

$\mathrm{H}_{4 \mathrm{~b}}$ : The negative effect of corruption on trust in local government will be less significant with a higher level of perceived local government transparency for younger people compared to older adults.

\section{Research Method}

\subsection{Sample and Procedures}

To test these hypotheses and model, a quantitative methodology was applied by conducting a survey. The current research involves simple random sampling without replacement, giving every population unit (18 years old and older) equal probability of being selected in the sample. Simple 
random sampling is well-suited for situations where little information is available about the population, and data collection can be effectively conducted on randomly distributed elements.

This study is based on survey data collected from citizens randomly selected in Vasylkivska amalgamated territorial community (ATC) of the Dnipropetrovsk Oblast, Ukraine ${ }^{20}$ between 17 September and 1 October 2020. The size of the budget for 2020 was UAH 1,529,928,000 or USD 55,003,405. As for internal organisation, ATC's governing body consists of 12 departments and 56 public servants. The population of the community as of 1 January 2019 was 20,481 people. To determine the number of samples, Slovin's formula with 5 percent error was used (the minimum 378 is required). The total number of population or respondents for the study is 403 .

Data from the survey were collected through close-ended questionnaires. A cover letter was added to the questionnaire, containing a brief introduction to the purpose of the survey. The random-walk technique was applied to conduct a face-to-face interview with respondents. In this process, several starting points were selected using a boundary map of the ATC. Households were selected in such a way that those far from the village centre and the main road had an equal chance of being sampled compared to more easily accessible households.

Demographic data were collected on gender and age. The most frequently observed category of gender was female $212(52.6 \%)$. The age profile presented as follows: young adults (ages 18-40; $\mathrm{n}=228,56.6 \%$ ), middle-aged adults (ages 41-60, $\mathrm{n}=153,37.9 \%$ ), and older adults (aged above $61, \mathrm{n}=22,5.5 \%)$. The majority of the respondents were aged 31 to 60 , as citizens around this age are most vibrant and tend to go to various public offices to get services. Although the demographic characteristics of the sample may not be identical to the population distribution, the sample is relatively representative of the general population of Ukraine (for more details, see SSSU, 2013).

\subsection{Measurements}

In order to check the reliability and validity of the research tool and to assess the respondents' feedback on the survey, a pilot study was conducted

${ }^{20}$ Community passport of the Vasylkivska ATC of the Dnipropetrovsk Oblast, Ukraine. Available at https://vasilkivska.otg.dp.gov.ua/ua/nasha-gromada/pasport-otg 
prior to the final field survey. After performing the basic statistical analysis using SPSS version 25.0 and making the necessary adjustments to the questionnaire, the actual field data collection was carried out. The survey contained three scales (corruption, transparency, and trust) and 13 items presented in the form of statements.

Survey questionnaires were pre-coded with structured response categories from which respondents may choose. Participants were asked to rate each statement on a 5-point Likert scale, where strongly disagree was coded as 1 and strongly agree as 5 . Measurements of dependent and independent variables, shown in Table 1, were adapted with modifications from Park and Blenkinsopp (2011), and Beshi and Kaur (2019). Perceived transparency and trust in local government were tested with four statements, and perceptions of corruption were tested with five. After performing a reliability and confirmatory factor analysis, one item from the transparency scale was deleted, hence the subsequent analysis was done with 12 items. Table 1 shows the results of the confirmatory factor analysis conducted on all the items. The three factors explain 67.873 percent of the total variance, supporting the handling of the key variables as conceptually distinct and empirically distinguishable. The integration of subfactors into one scale facilitates the analysis, so the scores for each element were averaged (meaning were calculated) to reflect the overall score of each variable.

Table 1. Results of the factor analysis on the question items for Perceived Corruption, Perceived Local Government Transparency and Trust in Local Government $(\mathrm{N}=403)$

\begin{tabular}{|c|c|c|c|c|}
\hline \multirow{2}{*}{\multicolumn{2}{|c|}{ Variables Items }} & \multicolumn{3}{|c|}{ Factors } \\
\hline & & \multirow{2}{*}{$\begin{array}{c}1 \\
0.311\end{array}$} & \multirow{2}{*}{$\begin{array}{c}2 \\
-0.148\end{array}$} & \multirow{2}{*}{$\begin{array}{c}3 \\
0.733\end{array}$} \\
\hline Transparency & $\operatorname{Tr}_{1}$ & & & \\
\hline & $\mathrm{Tr}_{2}$ & 0.256 & -0.157 & 0.734 \\
\hline & $\mathrm{Tr}_{3}$ & 0.296 & -0.112 & 0.810 \\
\hline \multirow[t]{4}{*}{ Corruption } & $\mathrm{C}_{1}$ & -0.039 & 0.637 & -0.491 \\
\hline & $\mathrm{C}_{2}$ & -0.060 & 0.793 & -0.323 \\
\hline & $\mathrm{C}_{3}$ & -0.129 & 0.690 & -0.186 \\
\hline & $\mathrm{C}_{4}$ & -0.036 & 0.712 & -0.033 \\
\hline
\end{tabular}




\begin{tabular}{|l|c|c|c|c|}
\hline & $\mathrm{C}_{5}$ & -0.261 & 0.728 & -0.101 \\
\hline Trust & $\mathrm{T}_{1}$ & 0.788 & -0.078 & 0.172 \\
\hline & $\mathrm{T}_{2}$ & 0.853 & -0.075 & 0.256 \\
\hline & $\mathrm{T}_{3}$ & 0.883 & -0.114 & 0.235 \\
\hline & $\mathrm{T}_{4}$ & 0.830 & -0.116 & 0.257 \\
\hline Eigenvalues & & 4.955 & 2.094 & 1.096 \\
\hline Cumulative percentages & 41.289 & 58.742 & 67.873 \\
\hline \multicolumn{2}{|l}{ 1. Extraction Method: Principal Component Analysis. } \\
\hline \multicolumn{4}{l}{ 2. Rotation method: Varimax with Kaiser normalisation. } \\
\hline
\end{tabular}

Source: Authors.

The dependent variable of the study, i.e. trust in local government, was operationalised through the question involving the extent to which the respondents agreed with the following statements:

1) Local government officials are acting in the interest of the community and place the interests of residents above their own in public work.

2) Officials of the local government institutions are capable.

3) Officials of the local government institutions carry out their duties effectively.

4) Local government officials are sincere and honest.

Park and Blenkinsopp (2011) measured the level of perceived trust with similar items, based on the definition that citizens' trust is a subjective judgment about the integrity, goodwill, and competence of government. Similarly, Pasquier and Mobillard (2015) suggest that the level of trust in government can be assessed using such measurements as competence, probity and benevolence. Cronbach's $\alpha$ on this scale is 0.902 , denoting good consistency between the targeted items.

The independent variable of the study, i.e. perceived corruption, was operationalised through the following statements:

1) There are cases of abuse associated with the management of administrative-territorial units' property such as transfer of rights to or allocation of land plots.

2) There are cases of inappropriate participation of contractors that do not meet the required standards for public works projects. 
3) There are cases of granting benefits to certain participants of the procedure for the selection of suppliers of goods and services within the procurement competition.

4) There is an atmosphere that something valuable must be provided to officials in order to receive a specific service or to ensure that public works are completed without difficulties.

5) There is a bias in personal relations such as giving preferences in employment with local government bodies or communal (utility) enterprises to the relatives of the local government representatives.

The statements presented above correspond to the following studies. Park and Blenkinsopp (2011) assessed corruption on the basis of five points concerning the three elements of corruption suggested by Barker and Carter (1994). These elements are violations of the law, rules, regulations or ethical norms; abuse of office by civil servants; and direct or indirect benefits received or expected from such a violation. Cronbach's alpha statistics on the scale show good reliability with a value of .791 .

Beshi and Kaur (2019), in their study, considered perceived practices of transparency as a factor influencing the level of public confidence in local government. In a study conducted by Park and Blenkinsopp (2011), transparency is presented as a moderator in the relationship between corruption and citizens' satisfaction with the services received. In this study, the perceived local government transparency variable was operationalised using the statements presented below with a Cronbach's alpha value of .798, showing a good internal consistency:

1) Local government projects and programmes are implemented transparently.

2) Residents can clearly see the progress of the local government institutions' work.

3) Local government institutions disclose sufficient information to the residents about their performance.

\subsection{Data Analysis}

This study involves getting a statistical generalisation of the respondents' attitudes and opinions towards the performance of local government in Ukraine. Perceiving the opinion of citizens helps in attaining the main objective of the study, i.e. to analyse the relationship between corruption and trust in government, and the effect of transparency in that relation- 
ship at the local level. After collecting the data, descriptive statistics and intercorrelations were calculated, then the linear relationships between the variables were examined using multiple regression analysis, and lastly, the regression-based bootstrapping approach described by the Hayes PROCESS macro (Hayes, 2017) was applied to validate the conceptual model and hypotheses using the Statistical Package for Social Sciences (SPSS) 25.0 software.

\section{Results of the Analysis and Discussion of Findings}

\subsection{Results of the Analysis}

As shown in Table 2, the main research variables are correlated, without suspicion of multicollinearity. ${ }^{1}$ Statistical assumptions of normality ${ }^{2}$ and homoscedasticity ${ }^{3}$ for predictors were assessed and met as well.

Table 2. Means, standard deviations, and correlations $(\mathrm{N}=403)$

\begin{tabular}{|c|c|c|c|c|c|c|c|}
\hline$\square$ & $\square$ & Mean & SD & 1 & 2 & 3 & $(\alpha)$ \\
\hline 1. & Trust & 3.85 & 0.62 & 1.000 & & & .717 \\
\hline 2. & Corruption & 2.13 & 0.68 & $-0.409^{* *}$ & 1.000 & & .797 \\
\hline 3. & Transparency & 3.76 & 0.78 & $0.519 * *$ & $-0.284^{* *}$ & 1.000 & .903 \\
\hline \multicolumn{8}{|c|}{$\begin{array}{l}\text { ** Correlation is significant at the } 0.01 \text { level (2-tailed). } \\
\text { Source: Authors. }\end{array}$} \\
\hline \multicolumn{8}{|c|}{$\begin{array}{l}{ }^{1} \text { Values of such diagnostic factors as tolerance and Variance Inflation Factor (VIF) } \\
\text { were far from the values that indicate multicollinearity between independent variables (less } \\
\text { than } 0.10 \text { and above } 10 \text { ). For Satisfaction, the Tolerance score is } .440 \text { and VIF is } 2.271 \text {; for } \\
\text { Corruption, the Tolerance score is } .888 \text { and VIF is } 1.126 \text {; for Transparency, the Tolerance } \\
\text { score is } .456 \text { and VIF is } 2.271 \text {. }\end{array}$} \\
\hline \multicolumn{8}{|c|}{$\begin{array}{l}{ }^{2} \text { The assumption of normality was assessed by plotting the quantiles of the model } \\
\text { residuals against the quantiles of a Chi-square distribution, also called a Q-Q scatterplot } \\
\text { (DeCarlo, 1997). The quantiles of the residuals were not strongly deviated from the theoret- } \\
\text { ical quantiles. Thus, the assumption of normality was met. }\end{array}$} \\
\hline & $\begin{array}{l}\text { Homoscedast } \\
\text { eld, 2017). The }\end{array}$ & was ev & ed by & $\begin{array}{l}\text { tting the } \\
\text { lly distril } \\
\text { edasticity }\end{array}$ & $\begin{array}{l}\text { esiduals ą } \\
\text { uted with }\end{array}$ & $\begin{array}{l}\text { st the } \\
\text { iean }\end{array}$ & $\begin{array}{l}\text { cted val- } \\
\text { and no }\end{array}$ \\
\hline
\end{tabular}


According to the results in Table 2, a significant negative correlation was observed between perceived corruption and perceived local government transparency $\left(r_{\mathrm{p}}=-0.284, p<.001\right)$. The correlation coefficient between perceived corruption and perceived local government transparency was -0.284 , indicating a moderate effect size. This correlation indicates that as perceived local government transparency increases, the perception of corruption tends to decrease. A significant negative correlation was observed between the perceived level of corruption and trust in local government $\left(r_{\mathrm{p}}=-0.409, p<.001\right)$. The correlation coefficient between perceived corruption and trust in local government was -0.409 , indicating a moderate effect size. This correlation indicates that as perceived corruption increases, trust in local government tends to decrease, supporting Hypothesis $\mathrm{H}_{1}$ at the zero-order level: as perceptions of corruption become more serious, this leads to a reduction in trust in the government.

According to the results in Table 2, the perception of local government transparency and trust in local government were positively related $\left(r_{\mathrm{p}}=\right.$ $0.519, p<.001)$. In other words, the more local government provides information to citizens, the more its residents are satisfied with the local government and tend to trust it. This output supports $\mathrm{H}_{2}$ and indicates a zero-order level relationship. In addition, after running a standard multiple regression analysis to examine individual predictors, it was found that among elements of transparency that better predict movements in the dependent variable, i.e. trust in local government, elements $1(B=$ $0.411, p<0.01)$ and $3(B=0.419, p<.001)$ can be selected as significant predictors in the model.

Hypothesis $\mathrm{H}_{3}$ posited a moderating effect of perceived local government transparency on the relationship between perceived corruption and trust in local government. The mean sample value, plus and minus one standard deviation from the mean were used to represent moderate, high and low transparency of local government according to the Hayes (2020) PROCESS macro (Model \#1) for SPSS. The analysis confirmed that the relationship between perceived corruption and trust in local government depends on the perceived transparency of local government (Table 3 and Figure 2), with a total share of $37 \%$ of the variance in trust in local government. Moderation is displayed by a significant effect of interaction, $B$ $=0.187,95 \% \operatorname{IP}[0.0915,0.2832], t=3.84, p<.001$, indicating that the relationship between perceived corruption and trust in local government is moderated by perceived local government transparency. These findings support $\mathrm{H}_{3 \mathrm{a}}$ and correspond to the proposal presented above. 
Table 3. Analysis of moderation of Perceived Corruption on Trust in Local Government by Perceived Local Government Transparency $\left(\mathrm{H}_{3}\right)$

\begin{tabular}{|c|c|c|c|}
\hline \multirow{2}{*}{$\square$} & \multicolumn{3}{|c|}{ Dependent variable $=$ Trust in Local Government } \\
\hline & \multicolumn{3}{|c|}{$\mathrm{R}^{2}=0.37$} \\
\hline Predictor & $B$ & $S E$ & $t$ \\
\hline Constant & 3.874 & .0259 & 149.676 \\
\hline Corruption & -.2759 & .0381 & -7.236 \\
\hline Transparency & .3415 & .0332 & 10.286 \\
\hline Corruption $_{\mathrm{x}}$ Transparency & .1873 & .0488 & $3.841^{* *}$ \\
\hline \multirow[t]{2}{*}{$\square$} & \multicolumn{3}{|c|}{$\begin{array}{l}\text { Simple slopes for Perceived Local } \\
\text { Government Transparency }\end{array}$} \\
\hline & \multicolumn{3}{|c|}{$\mathrm{M} \pm 1 \mathrm{SD}$} \\
\hline Transparency & $B$ & $S E$ & $t$ \\
\hline$-1 \mathrm{SD}$ & -.4223 & .0568 & -7.434 \\
\hline M & -.2759 & .0381 & -7.236 \\
\hline$+1 \mathrm{SD}$ & -.1295 & .0509 & $-2.545^{\star}$ \\
\hline
\end{tabular}

Notes: $\mathrm{n}=403 ;{ }^{*} p<.05,{ }^{* *} p<.001$.

Data were collected at the local level.

Source: Authors.

Moreover, when perceived local government transparency was low, perceived corruption was significantly and negatively $(B=-0.422 ; p<.001)$ related to trust in local government. At the moderate level of perceived local government transparency, there is a less significant negative effect $(B$ $=-0.275 ; p<.001$, ) of perceived corruption on trust in local government, with the effect approaching zero $(B=\sim 0.130 ; p=.011)$ at high perceived levels of local government transparency. Figure 2 represents an accurate illustration of these relationships, supporting Hypothesis $\mathrm{H}_{3 \mathrm{~b}}$. 
Figure 2. Moderation effect of Perceived Corruption on Trust in Local Government by Perceived Local Government Transparency $\left(\mathrm{H}_{3}\right)$

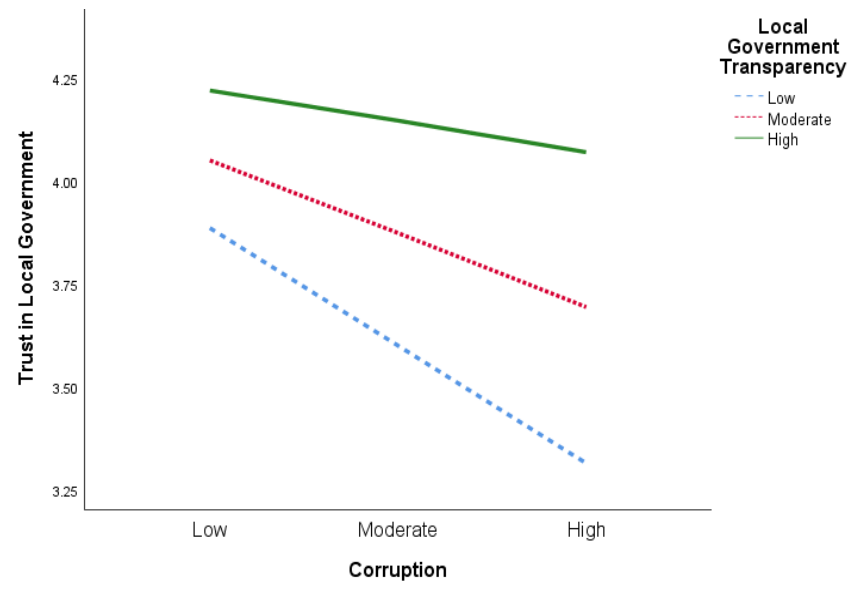

Source: Authors.

Next, it was assumed in $\mathrm{H}_{4 \mathrm{a}}$ that younger people perceive government as more transparent and therefore have greater trust. Results of the Pearson correlation (see Table 4) confirm that the strength of the relationship between perceived local government transparency and trust in local government differs depending on the respondents' age. It was indicated that there is a significant positive association within the groups of respondents in the age range from 18 to $40\left(r_{\mathrm{p}}=0.648, p<.001\right)$, compared to respondents in the age range from 41 and older $\left(r_{\mathrm{p}}=0.351, p<.001\right.$. These findings support $\mathrm{H}_{4 a}$ and correspond to the proposal presented above.

Table 4. Range of correlation coefficients between Perceived Local Government and Trust in Local Government by age groups

\begin{tabular}{|c|c|c|c|}
\hline$\square$ & \multicolumn{3}{|c|}{ Age range of respondents } \\
\hline$\square$ & $18-40$ & $41-60$ & 61 and above \\
\hline Coefficient & $.648^{* *}$ & $.351^{* *}$ & 0.214 \\
\hline
\end{tabular}

** Correlation is significant at the 0.01 level (2-tailed).

Source: Authors.

In order to confirm the statement of Hypothesis $\mathrm{H}_{4 \mathrm{~b}}$, the Hayes (2020) PROCESS macro (Model \#3) for SPSS was used. As Table 5 illustrates, the conditional effect of corruption on trust in local government by local 
government transparency changes depending on the respondents' age, with the effect approaching zero and being marginal for young and older adults $(B=-0.038, p=n$.s. and $B=-0.184, p=.030$, respectively $)$.

Table 5. Conditional effect of Perceived Corruption on Trust in Local Government by Perceived Local Government Transparency and Age of Respondents

\begin{tabular}{|l|c|c|}
\hline \multicolumn{1}{|c|}{$\square$} & \multicolumn{2}{|c|}{ Age of Respondents } \\
\hline \multicolumn{1}{|c|}{ Transparency } & Young adults & Older adults \\
\hline Low & -0.348 & -0.489 \\
\hline Moderate & -0.193 & -0.337 \\
\hline High & $-0.038^{* *}$ & $-0.184^{*}$ \\
\hline
\end{tabular}

Notes: $\mathrm{n}=403 ;{ }^{*} p<.05,{ }^{* *} p=n . s$,

Data were collected at the local level.

Source: Authors.

In other words, these findings support $\mathrm{H}_{4 \mathrm{~b}}$ and are consistent with the proposal that the negative effect of corruption on trust in local government will be less significant at a higher level of perceived local government transparency for younger people compared to older adults. Figure 3 presents the exact illustration of these relationships.

Figure 3. Moderation effect of Perceived Local Government Transparency on Trust in Local Government by Age of Respondents $\left(\mathrm{H}_{4}\right)$

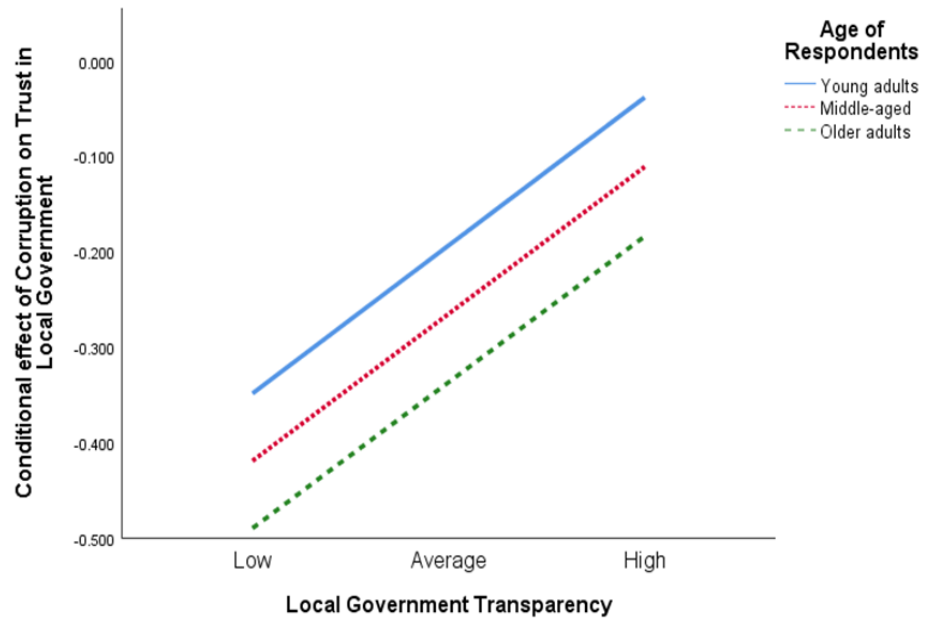

Source: Authors 


\subsection{Discussion of Findings}

The results of the study show that perceived corruption directly and indirectly correlates with citizens' trust in local government. Analysis of moderation of perceived corruption on trust in local government by perceived local government transparency was meaningful and important in a number of respects. As has been hypothesised, the perception of corruption negatively affects the level of public trust in local government $\left(\mathrm{H}_{1}\right)$. These findings accord with those of Villoria, Van Ryzin, and Lavena, (2013). The results of their research show that the perception of administrative and political corruption is associated with a lower level of satisfaction, as well as a lower level of institutional trust.

It was also confirmed that the perception of local government transparency and trust in local government were positively related $\left(\mathrm{H}_{2}\right)$. These findings accord with those of Song and Lee (2016), who found that governments can improve citizens' trust by enhancing their perceptions of government transparency. As Holzner and Holzner (2006) point out, transparency influences the relationship between citizens and government, encouraging governments to increase disclosure. Thus, this makes transparency an important factor to consider when developing policies aimed at reducing corruption and improving public confidence in government.

The results of the study also indicate that transparency serves as an important moderator in the relationship between corruption and trust. The negative impact of corruption on trust in local government was moderated by the effect of transparency $\left(\mathrm{H}_{3 \mathrm{a}}\right)$. These findings accord with previous studies concerning transparency as a determinant of corruption, such as Lindstedt and Naurin's (2010), who found support for the theoretical proposition that greater transparency lowers corruption. The results also show that at a low level of perceived local government transparency, corruption was significantly and negatively related to trust in local government, while within moderate and high perceived local government transparency the negative effect of corruption on trust in local government become less significant $\left(\mathrm{H}_{3 \mathrm{~b}}\right)$. Jimenez and Albalate, (2018) also found that by increasing the level of transparency and providing more information to citizens, local authorities reduce the likelihood of encountering cases of corruption and vice versa.

Other important findings to consider concern citizens' perceptions of local government transparency and corruption. First, as noted in the introductory part, local governments in Ukraine are undergoing significant 
changes as part of the decentralisation reform to ensure a more transparent, accountable and effective form of local self-government. If we consider Vasylkivska ATC, it is one of the newly created governing entities, which is expected to have a transparent and open government. However, the data in Table 1 show that the citizens of this community perceive local governments as insufficiently transparent. Assuming that the local government body of the Vasylkivska ATC provides sufficient information about its activities, it is important to consider whether the information provided actually reaches citizens and is received by them. Findings indicate that transparent implementation of local government projects and programmes, along with disclosure of sufficient information to the residents about its performance, may be considered as the most important elements of transparency from the citizens' perspective and, thus, could lead to greater trust of citizens in local government.

Publicity is, therefore, an important condition for transparency to be effective in reducing corruption, implying that available information is transmitted to and received by the public (Lindstedt \& Naurin, 2010). Kolsaker and Lee-Kelly (2008) suggest that low government transparency in terms of citizens' perceptions may be due to the fact that many citizens are either unaware of the existence of official government portals and e-sites, or simply do not use them, or do not always understand their content. Lindstedt and Naurin (2010) argue that the absence of intermediaries, such as the media or non-governmental organisations that can help access and process information, may result in transparent information not becoming public. This may help to explain the study findings revealing that the citizens' perception of local government transparency differs depending on the respondents' age: younger people perceive government as more transparent and therefore tend to have greater trust $\left(\mathrm{H}_{4 \mathrm{a}}\right)$. This difference in perception can be explained by the fact that younger people have access to and use modern communication platforms and technology to find information. These results are in line with Gonzálvez-Gallego and Nieto-Torrejón (2021), who have shown that young people assess government efforts to be more transparent and tend to have more trust in public institutions that provide public and open data. Thus, it brings us to the important conclusion that transparency itself has certain limitations as a method of increasing the level of citizens' trust in government, since simply providing information and being open is not enough to improve trust. Second, the results also indicate a relatively high level of perceived corruption. When considering the issue of trust and perception of corruption in the countries of the former Soviet Union, it should also be borne in mind 
that it is possible that pre-existing mistrust in government is contributing to a greater perception of corruption by citizens. When comparing the countries that were part of the Soviet Union with established democracies, the former have a much lower level of trust in general (Habibov, Afandi \& Cheung, 2017). As Markova (2004) noted, forced socialisation contributed to an atmosphere of mistrust in communist societies. The process of economic and political transition after the collapse of the Soviet Union was marked by economic downturn, social inequality and poverty, which further weakened citizens' trust in public institutions (Kubbe, 2013), leading also to increased corruption (Walker, 2011).

Surveys that study corruption usually find that the level of perceived corruption in the countries of the former Soviet Union is higher than in other countries of Central and Eastern Europe (Transparency International, 2019). Such unfavourable conditions challenged the implementation of public administration and management reforms in the region (Bouckaert, Nakrošis \& Nemec, 2011). It was confirmed through the analysis that the negative effect of perceived corruption on trust in local government was more significant for older adults compared to younger people $\left(\mathrm{H}_{4 \mathrm{~b}}\right)$, testifying to a long-range impact of the Soviet legacy on the consciousness of citizens. These findings correspond with the results of the study done by Torgler and Valev (2006), showing that justifiability of corruption is significantly lower for older adults compared to the younger generation, which is more likely to perceive corruption as a justifiable act.

As older people tend to view corruption as more widespread, it becomes difficult for Ukrainian local governments to earn the trust of their citizens. Therefore, local authorities should place greater emphasis on the implementation of transparency policies based on open data in order to continue to build trust, especially among the younger generation. Bauhr and Grimes (2017) suggest that government transparency can be linked to three kinds of purposes, such as deliberation, predictability, and accountability. In terms of deliberation, transparency in policy development promotes greater and meaningful participation. In this regard, Kweit and Kweit (2007) found that a sense of association with a particular public policy may be very important for citizens, and therefore can have a serious impact on the development of better relations between citizens and the state at the local level.

With regard to accountability, as a purpose of transparency, it is linked to anti-corruption efforts. Based on the principal-agent theory, Lindstedt and Naurin (2010) suggest that the accountability condition implies that 
increased transparency and publicity can lead to changes in the agent's behaviour only when the agent realises that the principal will act and impose a sanction mechanism (accountability costs). Thus, citizens must also possess some sanctioning mechanism to hold the government accountable. With respect to the political system, the ability of citizens (as the principal) to elect a government (as the agent) in general elections and the right to hold a referendum can be considered as the most important mechanisms of sanctioning. With regard to the referendum, the most important milestone in the successful implementation of this mechanism of direct democracy is the existence of special legislation along with the developed mechanism for implementing the decisions reached. Unfortunately, in Ukraine there is no legislative support for holding referendums and most of the conditions set by experts and specialists for their holding are absent, so the introduction of this instrument of direct democracy must be preceded by serious preparatory work.

\section{Conclusion}

From the public administration perspective, studying the impact of corruption on trust in government is of considerable importance. However, it is equally important to understand the role of transparency and its impact on the citizens' attitudes towards the government. The results of this study demonstrate the complex nature of the relationship between variables, and provide a platform for further research to deepen its understanding. The study highlights some important issues regarding perception of transparency at the local level and the role it plays in curbing corruption and improving public confidence in government, which need further exploration. The results are in accord with Lindstedt and Naurin (2010), who acknowledged that simply providing information and making it available can do little to prevent corruption, and emphasise the importance of intermediaries, such as the media or NGOs, who can help in accessing and processing the available information. As for the perception of transparency by the public, it will be useful for local authorities to pay more attention to how and what information citizens receive on government activities. Findings show that younger people tend to trust government institutions markedly more than older generations. Thus, local authorities need to strengthen their implementation of open data transparency policies to 
further build trust among these age groups and strengthen the younger generation's inclination towards democratic institutions.

It is also essential that citizens have a certain sanctioning mechanism to hold the government accountable. Thus, reforms aimed at increasing transparency are better implemented in conjunction with the measures aimed at strengthening the ability of people to act in line with the information they have. As it to some extent depends on other factors, transparency itself has certain limitations in deterring corruption. Therefore, adherence to democratic principles and the rule of law are very important in building and strengthening relations between citizens and the state.

In addition to this, Kweit and Kweit (2007) suggest that a sense of association with a particular public policy may be very important for citizens, and therefore can have a serious impact on the development of better relations between citizens and the state at the local level.

Although the general preconditions and challenges faced by the newly established governing bodies of ATCs, such as addressing corruption and low level of public trust, are common enough for the findings to be applicable to local authorities in other regions, generalisation of the study findings may be somewhat limited when considering the international level. Thus, despite its relevance in the Ukrainian context, the study has some limitations, and therefore several recommendations for further research will be offered below.

Since this paper focuses on Ukraine and the study findings are based on the case of a single local community, repeating a similar approach in other regions will allow for comparing and exploring different patterns that explain the connections analysed in this paper. Future research may also be of interest to compare research results with examples from other countries, as well as to use other explanatory models that have a comparative cross-cultural and longitudinal perspective. Future studies may also use additional variables along with corruption and transparency. Another issue of concern is the potential endogeneity of the model, caused by the possibility that the data collected perceived effects at some point in time, so it can be expected that as local authorities improve publicity and because citizens increasingly use open data tools, the effect size may change. While acknowledging its limitations, the study offers a unique perspective on the long-range impacts of the Soviet legacy (which left an imprint not only on the structure of local governments but above all in the consciousness and expectations of citizens regarding power) in the light of initiatives on decentralisation and in the context of the post-Soviet states. 


\section{References}

Anderson, C. J., \& Tverdova, Y. V. (2003). Corruption, political allegiances, and attitudes toward government in contemporary democracies. American Journal of Political Science, 47, 91-109, https://doi.org/10.1111/1540-5907.00007

Arnold, C, Sapir, E, \& Zaapryanova, G. (2012). Trust in the institutions of the European Union: A cross-country examination. Beyond Euro-Skepticism: Understanding attitudes towards the EU. European Integration Online Papers, Special Mini.Issue, 2(16), 1-39, http://eiop.or.at/eiop/texte/2012-008a.htm.

Askvik, S., Jamil, I. \& Dhakal, T.N. (2011). Citizens' trust in public and political institutions in Nepal. International political science review, 32(4), 417-437, https://doi.org/10.1177/0192512110377437

Aristovnik, A., (2012). Fiscal decentralization in Eastern Europe: a twenty-year perspective. Munich Personal RePEc Archive. Retrieved from https://mpra. ub.uni-muenchen.de/39316/1/MPRA_paper_39316.pdf

Barker, T., \& Carter, D.L. (1994). Police Deviance (3rd edn). Cincinnati, OH: Anderson

Bok, D. (1997). Measuring the performance of government. In: J.S. Nye, P.D. Zelikow, \& D.C. King (Eds.), Why People Don't Trust Government (pp. 55-75). Cambridge, MA: Harvard University Press

Bauhr M., \& Grimes, M. (2014). Indignation or resignation: The implications of transparency for societal accountability. Governance, 27(2), 291-320, https:// doi.org/10.1111/gove. 12033

Bauhr M., \& Grimes, M. (2017). Transparency to curb corruption? Concepts, measures and empirical merit. Crime, Law and Social Change, 68, 431-458, https://doi.org/10.1007/s10611-017-9695-1

Beshi, T. D., \& Kaur, R. (2019). Public trust in local government: Explaining the role of good governance practices. Public Organization Review, 20, 337-350, https://doi.org/10.1007/s11115-019-00444-6

Bouckaert, G., Nakrošis, V., \& Nemec, J. (2011). Public administration and management reforms in CEE: Main trajectories and results. NISPAcee Journal of Public Administration and Policy, 4(1), 9-29, https://doi.org/10.2478/v10110011-0001-9

Bilous, A., \& Tyshchuk, T. (2019). Civil service reform in Ukraine: Patterns of success in reforming institutions. Report, VoxUkraine. Retrieved from https:// voxukraine.org/wp-content/uploads/2019/09/Vox_Report_Final_for_Sharing_230819_IS-s.pdf

Cook, F.L., Jacobs, L.R., \& Kim, D. (2010). Trusting what you know: Information, knowledge, and confidence in social security. Journal of Politics 72(2), 397-412, https://doi.org/10.1017/S0022381610000034

Cooper, C. A., Gibbs, H. K. \& Brennan, K. M. (2008). The importance of trust in government for public administration: The case of zoning. Public Administration Review, 68(3), 459-468, https://doi.org/10.1111/j.1540-6210.2008.00882.x 
Cooray, A., \& Schneider, F. (2018). Does corruption throw sand into or grease the wheels of financial sector development? Public Choice 177, https://doi. org/10.1007/s11127-018-0592-7

Council of Europe, (2017). Handbook on Transparency and Citizen Participation in Ukraine. Retrieved from https://rm.coe.int/ukraine-handbook-on-transparency-and-citizen-participation-en/16807893c3, https://doi. org/10.18411/a-2017-023

Council of Europe. (2019). Decentralisation and reform of local self-government: Results of the fourth wave of sociological research. Retrieved from http:// www.slg-coe.org.ua/wp-content/uploads/2019/03/Соціологічнедослідженнящ ододецентралізаціїУкраїна_eng_.pdf

Cabinet of Ministers of Ukraine (CMU), (2020). Decentralization reform. Retrieved from https:/www.kmu.gov.ua/en/reformi/efektivne-vryaduvannya/ reforma-decentralizaciyi

DeCarlo, L. T. (1997). On the meaning and use of kurtosis. Psychological Methods, 2(3), 292-307, https://doi.org/10.1037/1082-989X.2.3.292

Dimant, E., \& Tosato, G. (2017). Causes and effects of corruption: What has past decade's empirical research taught us? A survey. Journal of Economic Surveys, 32(2), 335-356, https://doi.org/10.1111/joes.12198.

European Union, (2011). Local and regional government in Ukraine and the development of cooperation between Ukraine and the EU. Retrieved from https://cor.europa.eu/en/engage/studies/Documents/local-regional-government-ukraine.pdf

Field, A. (2017). Discovering statistics using IBM SPSS statistics: North American edition. University of Sussex, UK: Sage Publications.

Florini, A. (2007). Introduction. The battle over transparency. In A. Florini (Ed.), The right to know (pp. 1-16). New York Chichester, USA: Columbia University Press, https://doi.org/10.7312/flor14158-intro

Fukuyama, F. (2001). Social capital, civil society and development. Third World Quarterly, 22(1), 7-20, https://doi.org/10.1080/713701144

Gerasymenko O.V., Splavinska A.Y., Pavliv M.A. (2018). Prozorist' i vidkrytist' informatsiyi yak zaporuka zapobihannya koruptsiynym proyavam $\mathrm{v}$ orhanakh derzhavnoyi vlady [Transparency and openness of information as a guarantee of prevention of corruption in public authorities] Young Scientist, 11(63), 975978. Retrieved from http://molodyvcheny.in.ua/files/journal/2018/11/224.pdf

Gonzalvez-Gallego, N., \& Nieto-Torrejon, L. (2021). Can open data increase younger generations' trust in democratic institutions? A study in the European Union. PLoS ONE 16(1), 1-14, https://doi.org/10.1371/journal. pone.0244994

Grimmelikhuijsen, S., Porumbescu, G., \& Tobin, H. B. I. (2013). The effect of transparency on Trust in Government: A cross-National Comparative Experiment. Public Administration Review, 73(4), 575-586, https://doi.org/10.1111/ puar. 12047 
Grimmelikhuijsen, S. G. (2012). Transparency and trust. An experimental study of online disclosure and trust in government (Dissertation, Utrecht University). Retrieved from https://dspace.library.uu.nl/handle/1874/218113

Hayes, A. F. (2017). Introduction to mediation, moderation, and conditional process analysis: A regression-based approach. Second edition. New York, USA: Guilford Press.

Holzner, B., \& Holzner, L. (2006). Transparency in Global Change: The Vanguard of the Open Society. Pittsburgh, PA: University of Pittsburgh Press, https://doi. org/10.1086/592526

Hayes, A. F. (2020). The PROCESS macro for SPSS and SAS. Retrieved from http://www.processmacro.org/index.html

Habibov, N., Afandi, E. \& Cheung, A. (2017). Sand or grease? Corruption-institutional trust nexus in post-Soviet countries. Journal of Eurasian Studies, 8(2), 172-184, https://doi.org/10.1016\%2Fj.euras.2017.05.001

Hetherington, M. (1998). The political relevance of political trust. The American Political Science Review, 92(4), 791-808, https://doi.org/10.2307/2586304

Jiménez, J., \& Albalate, D. (2018). Transparency and local government corruption: what does lack of transparency hide? European Journal of Government and Economics, 7, 106-122, https://doi.org/10.17979/ejge.2018.7.2.4509

Klesner, J. (2007). Social capital and political participation in Latin America: Evidence from Argentina, Chile, Mexico, and Peru. Latin American Research Review, 42(2), 1-32. Retrieved from www.jstor.org/stable/4499368, https://doi. org/10.1353/lar.2007.0022

Kolstad, I., \& Wiig, A. (2009). Is transparency the key to reducing corruption in resource-rich countries? World Development, 37(3), 521-532, https://doi. org/10.1016/j.worlddev.2008.07.002

Kolsaker, A., \& Lee-Kelley, L. (2008). Citizens' attitudes towards e-government and e-governance: A UK study. International Journal of Public Sector Management, 21(7), 723-738, https://doi.org/10.1108/09513550810904532

Kubbe, I. (2013). Corruption and trust: A model design. Zeitschrift für Vergleichende Politikwissenschaft, 7, 117-135, https://doi.org/10.1007/s12286-013-0159-4

Kweit, M. G., \& Kweit, R. W. (2007). Participation, perception of participation, and citizen support. American Politics Research, 35(3), 407-425, https://doi. org/10.1177\%2F1532673X06296206

Lanin, D., \& Hermanto, N. (2019). The effect of service quality toward public satisfaction and public trust on local government in Indonesia. International Journal of Social Economics, 46(3), 377-392, https://doi.org/10.1108/IJSE-042017-0151

Lindstedt C., \& Naurin D., (2010). Transparency is not enough: Making transparency effective in reducing corruption. International Political Science Review, 31(3) 301-32, https://doi.org/10.1177\%2F0192512110377602

Lindegaard, L. S., \& Webster, N. 1. (2018). Decentralisation in Ukraine. Supporting political stability by strengthening local government. Report, DIIS - 
Danish Institute for International Studies. Copenhagen, Denmark. Retrieved from https://www.econstor.eu/bitstream/10419/197625/1/1041288271.pdf

Lopushyns'ky I. P., (2013). Dovira do vlady yak derzhavotvorchyy chynnyk $\mathrm{v}$ Ukrayini. [Confidence in the government as a state-building factor in Ukraine]. Teoriya ta praktyka derzhavnoho upravlinnya $i$ mistsevobo samovryaduvannya, 2, 1-11, Retrieved from http://nbuv.gov.ua/UJRN/Ttpdu_2013_2_23.

Marková, I. (2004). Trust and democratic transition in post-communist Europe. New York, USA: Oxford University Press

Meijer, A. (2015). Government transparency in historical perspective: from the ancient regime to open data in the Netherlands. International Journal of Public Administration, 38, 189-199, https://doi.org/10.1080/01900692.2014.934837

Méon, P.G., \& Sekkat K. (2005). Does corruption grease or sand the wheels of corruption? Public Choice, 122, 69-97, https://doi.org/10.1007/s11127-0053988-0

Mishler, W., \& Rose, R. (2001). What are the origins of political trust? Testing institutional and cultural theories in post-communist societies. Comparative political studies, 34(1), 30-62, https://doi.org/10.1177/0010414001034001002

Menocal, A. (2015). Why corruption matters: understanding causes, effects, and how to address them. DFID Evidence Paper. London, UK: DFID Retrieved from: https://assets.publishing.service.gov.uk/government/uploads/system/ uploads/attachment_data/file/406346/corruption-evidence-paper-why-corruption-matters.pdf

Oliver, R., W. (2004). What Is Transparency? New York, USA: McGraw-Hill.

OECD (2013). Trust in government, policy effectiveness and the governance agenda. Government at a Glance 2013, OECD Publishing, Paris, https://doi. org/10.1787/gov_glance-2013-en

Prat, A. (2006). The more closely we are watched, the better we behave? In C. Hood \& D. Heald (Eds.), Transparency: The key to better governance? (pp. 91-103). Oxford, UK: Oxford University Press, https://doi.org/10.5871/ bacad/9780197263839.003.0006

Park, H., \& Blenkinsopp, J. (2011). The roles of transparency and trust in the relationship between corruption and citizen satisfaction. International Review of Administrative Sciences, 77(2), 254-274, https://doi. org/10.1177\%2F0020852311399230

Pasquier, M., \& Mabillard, V. (2015). Transparency and trust in government: A two-way relationship. Yearbook of Swiss Administrative Sciences, 6(1), 23-34, https://doi.org/10.5334/ssas.78

Piotrowski, S. J. (2017). The "Open government reform" movement: The case of the open government partnership and U.S. transparency policies. The American Review of Public Administration, 47(2), 155-171, https://doi. org/10.1177\%2F0275074016676575

Pozsgai-Alvarez J. (2019). The abuse of entrusted power for private gain: Meaning, nature and theoretical evolution. Japan-ASEAN Transdisciplinary Studies Working Paper Series, 5, 1-25. Retrieved from http://hdl.handle.net/2433/236574 
Reinikka, R., \& Svensson, J. (2005). Fighting corruption to improve schooling: Evidence from a newspaper campaign in Uganda. Journal of the European Economic Association, 3(2), 259-267, https://doi.org/10.1162/jeea.2005.3.2-3.259

Romanova, V. \& Umland, A. (2019). Ukraine's decentralization reforms since 2014 initial achievements and future challenges. London, UK: The Royal Institute of International Affairs, Chatham House. Retrieved from https://www.chathamhouse.org/sites/default/files/2019-09-24-UkraineDecentralization.pdf

Rousseau, D., Sitkin, S. B., Burt, R., \& Camerer, C. (1998). Not so different after all: A cross discipline view of trust. Academy of Management Review, 23(3), 393-404, https://doi.org/10.5465/amr.1998.926617

Song, C. S., \& Lee, J. H., (2016). Citizens' use of social media in government, perceived transparency, and trust in government. Journal Public Performance \& Management Review, 2, 430-453, https://doi.org/10.1080/15309576.2015.1 108798

Schöberlein, J. (2019). Lessons learned from anti-corruption efforts at municipal and city level. Transparency international U4 anti-corruption resource centre. Retrieved from https://www.u4.no/publications/lessons-learned-from-anti-corruption-efforts-at-municipal-and-city-level.pdf

SSSU, (2013). Загальна характеристика статево-вікового складу населення України на 1 січня 2013 року. [General characteristics of the sex and age composition of the population of Ukraine on January 1, 2013]. State statistics service of Ukraine. Retrieved from http://database.ukrcensus.gov.ua/PXWEB2007/ukr/publ_ new1/2013/dop_age_01012013.pdf

Torgler, W. B., \& Valev, N. T. (2006). Corruption and age. Journal of Bioeconomics, 8, 133- 145, https://doi.org/10.1007/s10818-006-9003-0

Twenge, J. M., Campbell, W. K., \& Carter, N. T. (2014). Declines in trust in others and confidence in institutions among American adults and late adolescents, 1972-2012. Psychological Science, 25(10), 1914-1923, https://doi. org/10.1177/0956797614545133

Transparency International (2019). Transparency International corruption perceptions index 2019. Retrieved from https://www.transparency.org/cpi2019, https://doi.org/10.1787/888932539574

Van de Walle, S. (2011). New public management: Restoring the public trust through creating distrust? In: T. Christensen \& P. Lègreid (Eds), Ashgate research companion to new public management, 309-320. Aldershot, UK: Ashgate, https://doi.org/10.4324/9781315613321-31

Van der Meer, T., \& Hakhverdian, A. (2017). Political trust as the evaluation of process and performance: A cross-national study of 42 European countries. Political Studies, 65, 81-102, https://doi.org/10.1177\%2F0032321715607514

Villoria, M., Van Ryzin, G. G., \& Lavena, C. F. (2013). Social and political consequences of administrative corruption: A study of public perceptions in Spain. Public Administration Review, 73, 85-94, https://doi.org/10.1111/j.15406210.2012.02613.x 
Volianska, O. (2020). Dovira do publichnoyi vlady ta chynnyky, shcho yiyi zumovlyuyut' $\mathrm{u}$ nadzvychaynykh sytuatsiyakh. [Trust in public authorities and factors causing it in emergency situations]. Visnyk Natsional'nobo yurydychnobo universytetu imeni Yaroslava Mudrobo, 2 (45), 167-180, https://doi. org/10.21564/2075-7190.45.200938

Walker, C. (2011). The perpetual battle: Corruption in the former Soviet Union and the New EU members. Centre of Public Policy PROVIDUS. Paper No. 12, 2011. Retrieved from https://freedomhouse.org/sites/default/files/PerpetualBattle. pdf

Yates, A., \& Graycar, A. (2020). Death by a thousand cuts: Recognizing, reporting, and responding to corruption in local government. Public Integrity, 22(1), 85-103, https://doi.org/10.1080/10999922.2018.1534924

Zakharchuk, O. (2015). Zapobihannya koruptsiyi v orhanakh mistsevoho samovryaduvannya. L'vivs'kyy instytut MAUPb [Prevention of corruption in local government bodies]. Aktual'ni problemy polityky, 55, 253-259. Retrieved from https://core.ac.uk/download/pdf/50596032.pdf

\title{
CITIZENS' PERCEPTION OF CORRUPTION AND TRANSPARENCY AS DETERMINANTS OF PUBLIC TRUST IN LOCAL GOVERNMENT IN UKRAINE
}

\begin{abstract}
Summary
The Government of Ukraine is currently carrying out the decentralization and institutional reforms, designed to transform local governments and make them more efficient and effective. The constant drive for reform implementation is largely dependent on how citizens perceive the improvements of local government and local conditions through initial reforms, though attempts to ensure a positive perception take place in a difficult environment of the inherited low level of trust in public authorities. Studying the issue of citizens' trust in government on the example of amalgamated territorial communities belps us to see whether the emphasis on local self-government can ensure a promising approach to strengthening political stabilization and state-building in Ukraine and beyond. In the light of decentralization initiatives, this paper offers a unique perspective on the long-range impacts of the Soviet legacy that left an imprint on the structure of local governments and in the consciousness and expectations of citizens. The findings demonstrate a complex nature of the relationship between the variables and indicate some important issues regarding transparency and its perception that should be considered when developing policies aimed at reducing corruption
\end{abstract}


and improving public confidence in local governments. The author conclude that along with emphasis on local self-government, adherence to democratic principles and the rule of law are crucial in building and strengthening the relations between citizens and the state.

Keywords: citizens-state relationships, state-building, local government, trust in government, corruption, transparency, Ukraine

\section{PERCEPCIJA KORUPCIJE I TRANSPARENTNOSTI KAO ODREDNICE POVJERENJA JAVNOSTI U LOKALNE VLASTI U UKRAJINI}

\section{Sažetak}

Ukrajinska vlada provodi decentralizacijske $i$ druge institucijske reforme radi preoblikovanja $i$ postizanja veće efikasnosti $i$ efektivnosti lokalne samouprave. Percepcija dosadašnjih pokušaja poboljšanja lokalne samouprave $i$ životnih uvjeta na lokalnoj razini daje stalan poticaj novim reformama premda se osiguravanje pozitivnih promjena odvija u nepovoljnim uvjetima naslijeđene vrlo niske razine povjerenja u javne vlasti. Istraživanje povjerenja građana u vlast na primjeru ukrajinskib lokalnih jedinica koje su nastale kao plod spajanja prijašnjih manjih jedinica pomaže provjeriti ideju o lokalnoj samoupravi kao osloncu stabilizacije i izgradnje državnih institucija u Ukrajini i šire. U svjethu decentralizacijskib inicijativa ispituju se dugoročni duboki učinci sovjetskog naslijeđa na strukturu lokalne samouprave te na očekivanja i svijest građana o političkoj vlasti. Otkriva se složena priroda odnosa među glavnim varijablama i naglašavaju neki važni aspekti transparentnosti $i$ njezine percepcije koje bi trebalo uzeti u obzir kod oblikovanja politike borbe protiv korupcije i jačanja povjerenja javnosti u lokalne vlasti. Rad zaključuje da je za izgradnju i jačanje odnosa između građana $i$ države uz lokalnu samoupravu važna $i$ privrženost demokratskim načelima i vladavini prava.

Ključne riječi: odnos građana $i$ države, izgradnja državnib $i$ javnib institucija, lokalna samouprava, povjerenje u vlast, korupcija, transparentnost, Ukrajina 